\title{
Analisis Keterampilan Guru Dalam Mengadakan Variasi Pembelajaran Tematik Kelas 1 SDN 1 Gondang Kabupaten Tulungagung
}

\author{
Anik Susanti ${ }^{1}$, Nugrananda Janattaka ${ }^{2}$ \\ Program Studi (PGSD) STKIP PGRI Tulungaung ${ }^{1,2}$ \\ aniksusanti110696@gmail.com ${ }^{1}$, nugrananda@stkippgritulungagung.ac.id ${ }^{2}$
}

\begin{abstract}
Abstrak
Guru dalam proses pembelajaran mempunyai peranan yang sangat penting. Keterampilan mengadakan variasi pembelajaran Tematik merupakan keterampilan yang harus dimiliki oleh seorang guru. Pada kondisi di lapangan masih ada beberapa keterampilan yang belum muncul atau terpenuhi. Tujuan penelitian ini adalah untuk mengetahui keterampilan guru dalam mengadakan variasi pembelajaran tematik di kelas 1 dan untuk mengetahui respon siswa terhadap variasi pembelajaran guru kelas 1. Jenis penelitian ini adalah penelitian deskriptif. Teknik pengumpulan data menggunakan observasi, wawancara dan dokumentasi. Teknik analisis data menggunakan analisis deskriptif kualitatif. Instrumen yang digunakan yaitu berupa pedoman observasi keterampilan guru, pedoman observasi aktivitas siswa dan pedoman wawancara dengan guru. Hasil penelitian ini adalah secara keseluruhan dari kedua kelas dalam menguasai keterampilan mengadakan variasi pembelajaran tematik mendapatkan kategori baik. Perolehan skor tertinggi dari kedua kelas yaitu kelas IA sebesar 85\% dengan kriteria baik, sedangkan untuk kelas IB sebesar $81.25 \%$ dengan kriteria baik. Selain itu keterampilan guru dalam mengadakan variasi pembelajaran berpengaruh pada respon siswa yang menunjukkan siswa aktif, antusias, konsentrasi, dan tertarik untuk mengikuti pembelajaran tematik dikelas.
\end{abstract}

Kata kunci: Guru, Keterampilan, Variasi Pembelajaran 


\section{PENDAHULUAN}

Pendidikan merupakan suatu usaha sadar dan sistematis yang dilakukan oleh seseorang untuk mengubah tangkah laku manusia ke arah yang lebih baik dengan berbagai cara dan strategi dalam mencapai tujuan pendidikan. Menurut Mulyasa (2012, hal. 46) kurikulum adalah seperangkat rencana dan pengaturan mengenai tujuan, kompetensi dasar, materi standar, hasil belajar, serta cara yang digunakan sebagai pedoman penyelenggaraan kegiatan pembelajaran untuk mencapai kompetensi dasar dan tujuan pendidikan. Kurikulum 2013 (K13) adalah kurikulum yang berlaku dalam sistem pendidikan Indonesia saat ini yang telah ditetapkan pemerintah untuk menggantikan Kurikulum-2006 atau disebut dengan Kurikulum Tingkat Satuan Pendidikan (KTSP) dan menerapkan pendekatan pembelajaran tematik.

Pembelajaran tematik adalah suatu pendekatan dalam pembelajaran yang secara sengaja mengaitkan beberapa aspek baik dalam intra pelajaran maupun antar mata pelajaran ke dalam berbagai tema (Majid (2014, hal. 78). Berkaitan dengan pembelajaran tematik, keterampilan dasar sangat penting untuk dikuasai oleh guru. Salah satu dari keterampilan yang harus dikuasai oleh guru yaitu keterampilan mengadakan variasi pembelajaran. Menurut Mulyasa (2015, hal 78) keterampilan mengadakan variasi adalah suatu kegiatan guru dalam konteks proses interaksi pembelajaran yang ditujukan untuk menghilangkan kebosanan siswa dalam belajar, meningkatkan motivasi dalam mempelajari sesuatu, melayani gaya belajar siswa yang beraneka ragam, dan meningkatkan keaktifan/keterlibatan siswa dalam kegiatan pembelajaran. Mengadakan variasi dalam proses belajar mengajar meliputi tiga aspek, yaitu variasi gaya mengajar, variasi dalam penggunaan media dan bahan pengajaran, dan variasi dalam interaksi antar guru dan siswa (Syaiful dan Aswan (2010, hal 160).

Kurangnya variasi mengajar guru menjadi faktor penyebab kejenuhan siswa selama mengikuti pelajaran sehingga tidak memperhatikan guru yang sedang menjelaskan. Melakukan kegiatan pembelajaran yang sama secara terus menerus dapat menimbulkan kebosanan dan dapat menurunkan semangat belajar. Kebosanan siswa dalam proses pembelajaran dapat diamati selama proses belajar mengajar berlangsung seperti kurang perhatian, mengantuk, berlarian kesana kemari, 
mengobrol dengan sesama teman atau pura-pura mau ke kamar kecil hanya untuk menghindari kebosanan. Selain itu siswa kelas satu termasuk dalam kelas rendah yang mempunyai karakter suka bermain karena mereka berada pada tahap peralihan dari TK, senang bergerak kesana kemari, senang bekerja dalam kelompok dan senang melakukan sesuatu secara langsung.

Permasalahan yang ditemui di lapangan yaitu ketika pelajaran sedang berlangsung perhatian dan konsentrasi siswa tidak terkontrol. Siswa tidak memperhatikan penjelasan guru dan lebih suka ramai sendiri dengan temantemannya. Ketika guru menerangkan siswa berlarian kesana kemari, bermain dengan temannya, dan tidak menghiraukan apa yang instruksikan oleh guru. Sehingga pembelajaran tidak bisa optimal dan materi tidak bisa tersampaikan dengan baik. Sesuai latar belakang yang telah dikemukakan, maka peneliti tertarik untuk meneliti keterampilan guru dalam mengadakan variasi pembelajaran tematik kelas 1 SDN 1 Gondang Kabupaten Tulungagng.

\section{METODE PENELITIAN}

Jenis penelitian ini adalah penelitian deskriptif, dimana penelitian ini dimaksudkan untuk mendeskripsikan bagaimana keterampilan guru dalam mengadakan variasi pembelajaran tematik pada kelas 1 Sekolah Dasar. Pendekatan yang digunakan adalah pendekatan kualitatif deskriptif karena dalam penelitian ini digunakan untuk meneliti pada kondisi obyek yang alamiah supaya mendapatkan data yang mendalam dan mengandung makna (Sugiyono, 2015, hal.15). Tahap-tahap penelitian ini secara umum terdiri atas tahap pra-lapangan, tahap pekerjaan lapangan, dan tahap analisis data (Moleong, 2017, hal. 127).

Penelitian dilakukan pada bulan Maret s.d Juni 2019 Semester 2 tahun ajaran 2018/2019 di SDN 1 Gondang Kabupaten Tulungagung. Subjek dalam penelitian ini adalah guru kelas 1A dan 1B serta siswa perwakilan dari masing-masing kelas. Teknik pengumpulan data yang digunakan yaitu menggunakan observasi, wawancacra dan dokumentasi. Instrumen observasi digunakan untuk mengumpulkan data terkait keterampilan guru dan respon siswa selama kegiatan belajar di kelas. Wawancara dilakukan sebagai penguatan keterampilan guru dalam mengadakan variasi pembelajaran dikelas 1 dan dokumentasi dilakukan untuk mendapatkan data 
keterampilan guru mengadakan variasi pembelajaran dan respon siswa. Kisi-kisi penelitian dapat dilihat pada table dibawah ini:

Tabel 1. Kisi-kisi Instrumen Penelitian

\begin{tabular}{|c|c|c|c|c|c|}
\hline No. & Variabel & Aspek & Indikator & $\begin{array}{c}\text { Alat } \\
\text { instrumen }\end{array}$ & $\begin{array}{c}\text { Jumlah } \\
\text { butir }\end{array}$ \\
\hline 1 & $\begin{array}{l}\text { Keteram } \\
\text { pilan } \\
\text { guru }\end{array}$ & $\begin{array}{l}\text { Memberi } \\
\text { kan } \\
\text { variasi }\end{array}$ & $\begin{array}{l}\text { Variasi gaya mengajar } \\
\text { Variasi suara } \\
\text { Memusatkan perhatian } \\
\text { Mengadakan kontak } \\
\text { pandang } \\
\text { Variasi gerak badan dan } \\
\text { mimik } \\
\text { Membuat kesenyapan } \\
\text { Pergantian posisi } \\
\text { Variasi penggunaan } \\
\text { media dan } \\
\text { pembelajaran } \\
\text { Variasi media audio } \\
\text { Variasi media visual } \\
\text { Variasi pola interaksi } \\
\text { Variasi kegiatan. } \\
\text { Variasi pola interaksi } \\
\text { (Usman, 2013) }\end{array}$ & $\begin{array}{l}\text { Observasi } \\
\text { Wawancara } \\
\text { dokumentasi }\end{array}$ & $\begin{array}{l}10 \text { butir } \\
10 \text { butir } \\
\text { Foto dan } \\
\text { video }\end{array}$ \\
\hline 2. & Siswa & $\begin{array}{l}\text { Respon } \\
\text { siswa }\end{array}$ & $\begin{array}{l}\text { siswa mengondisikan diri } \\
\text { di dalam kelas } \\
\text { siswa memperhatikan } \\
\text { penjelasan guru } \\
\text { siswa fokus mengamati } \\
\text { objek pengamatan } \\
\text { siswa mengajukan } \\
\text { pertanyaan, dan berdiskusi } \\
\text { siswa menikmati proses } \\
\text { pembelajaran } \\
\text { siswa memanfaatkan }\end{array}$ & $\begin{array}{l}\text {.observasi } \\
\text { ¿.dokumentasi }\end{array}$ & $\begin{array}{l}.6 \text { butir } \\
\text { ¿.Foto dan } \\
\text { video }\end{array}$ \\
\hline
\end{tabular}


fasilitas media alat peraga

yang ditampilkan.

(Azwar, 2008)

\section{HASIL DAN PEMBAHASAN}

\section{HASIL}

Keterampilan guru dalam mengadakan variasi pembelajaran tematik kelas 1A dan IB di SDN 1 Gondang telah dilakukan guru secara baik dan bervariatif. Ini terlihat dari tabel dibawah :

Tabel 2. Persentase Keterampilan Guru Mengadakan Variasi Pembelajaran Tematik Kelas I di SD Negeri 1 Gondang Kabupaten Tulungagung

\begin{tabular}{lcc}
\hline \multicolumn{1}{c}{ Indikator } & Kelas IA & Kelas IB \\
\hline Variasi suara & $100 \%$ & $100 \%$ \\
\hline Penekanan & $87.5 \%$ & $93.75 \%$ \\
\hline Kesenyapan sejenak & $75 \%$ & $75 \%$ \\
\hline Kontak pandang & $100 \%$ & $93.75 \%$ \\
\hline Gerakan anggota badan & $93.75 \%$ & $87.5 \%$ \\
\hline Pindah posisi & $93.75 \%$ & $93.75 \%$ \\
\hline Variasi pola interaksi & $87.5 \%$ & $87.5 \%$ \\
\hline Variasi kegiatan & $100 \%$ & $100 \%$ \\
\hline Variasi media audio & $50 \%$ & $37.5 \%$ \\
\hline Variasi media visual & $62.5 \%$ & $43.75 \%$ \\
\hline Jumlah & $\mathbf{8 5 \%}$ & $\mathbf{8 1 . 2 5 \%}$ \\
\hline Kategori & Baik & Baik
\end{tabular}

Tabel 3. Ulasan Pengamatan Respon Belajar Siswa Kelas IA (FI)

\begin{tabular}{llll}
\hline No & Indikator respon siswa & \multicolumn{2}{c}{ Ulasan kegiatan } \\
\hline 1. & Siswa mengondisikan & Siswa duduk ditempat masing-masing dengan \\
& diri didalam kelas & rapi dan tenang. Pada awal proses apersepsi \\
& & siswa sangat memperhatikan dan menjawab apa \\
& & yang ditanyakan oleh guru. Siswa juga terkadang \\
& & berlari ke tempat duduk temannya untuk \\
& & meminjam penghapus. \\
\hline 2. & Siswa memperhatikan & Siswa sangat antusias dalam mendengarkan \\
& penjelasan guru & penjelasan dari guru dan siswa sangat aktif \\
& & menjawab pertanyaan dari guru kemudian \\
\hline
\end{tabular}




\begin{tabular}{ll}
\hline & menanyakan apa yang belum diketahuinya. \\
& Selama guru menerangkan pelajaran siswa sangat \\
& tenang dan tidak mengganggu teman yang lain. \\
& Pada tengah pelajaran siswa minta izin ke toilet \\
& untuk buang air lalu memperhatikan penjelasan \\
& dari guru dengan tenang. \\
\hline 3. Siswa fokus mengamati & Siswa sangat bersemangat dan antusias saat \\
objek pengamatan & diberikan tugas individu maupun tugas kelompok \\
& oleh guru. Saat kerja kelompok suasana kelas \\
& tidak terlalu gaduh dan siswa mengerjakan tugas \\
& kelompok dengan baik. Siswa juga menanyakan \\
& hal-hal yang belum diketahuinya dengan cara \\
& mengacungkan tangan. Setelah diskusi siswa \\
& juga diberikan \\
mempresentasikan hasil kerja kelompok ke depan & kelas.
\end{tabular}

\begin{tabular}{lll}
\hline 4. Siswa & mengajukan & Saat guru menerangkan didepan kelas siswa \\
pertanyaan & dan & kurang aktif menanyakan apa yang belum di \\
berdiskusi & mengerti tapi dengan kreativitas guru menggali \\
& pengetahuan siswa maka siswa tersebut menjadi \\
& lebih aktif untuk bertanya dan timbul rasa \\
& penasaran dengan materi yang di sampaikan \\
& guru. Pada saat kerja kelompok siswa enggan \\
& untuk mengerjakan tapi ketika didekati oleh guru \\
& siswa mau untuk mengerjakan tugasnya.
\end{tabular}

5. Siswa menikmati proses Pada saat pembelajaran dikelas interaksi antar pembelajaran siswa terjalin dengan baik. Jika ada siswa yang belum mengerti siswa yang lain memberikan penjelasan kepada siswa tersebut. Ketika berbicara dengan temannya siswa menggunakan Bahasa yang baik namun terkadang juga berbicara kurang sopan. Pada saat temannya presentasi didepan kelas siswa yang lain aktif memberikan tanggapannya dan memberikan tepuk tangan pada setiap penampilan siswa. 


\begin{tabular}{lll}
\hline 6. Siswa memanfaatkan & Pada saat pembelajaran guru menggunakan \\
fasilitas media dan alat & fasilitas papan tulis untuk mendukung \\
peraga & yang & pembelajaran. Siswa disuruh untuk menyebutkan \\
ditampilkan & benda-benda langit dan menggambarnya lalu \\
& dikaitkan dengan pembelajaran tematik lainnya. \\
& Selain itu siswa disuruh untuk menyanyikan lagu \\
& "matahari terbenam" secara bersama-sama dan \\
& menyimpulkan isi dari lagu tersebut.
\end{tabular}

Tabel 4. Ulasan Pengamatan Respon Belajar Siswa Kelas IB (ZAP)

\begin{tabular}{|c|c|c|}
\hline No & Indikator respon siswa & Ulasan kegiatan \\
\hline 1. & $\begin{array}{l}\text { Siswa mengondisikan diri } \\
\text { didalam kelas }\end{array}$ & $\begin{array}{l}\text { Siswa duduk ditempat masing-masing dengan rapi } \\
\text { dan tenang. Setelah diberikan instruksi dari guru } \\
\text { siswa mempersiapkan buku pelajarannya berupa } \\
\text { buku tematik. Pada awal proses apersepsi siswa } \\
\text { sangat memperhatikan dan menjawab apa yang } \\
\text { ditanyakan oleh guru. }\end{array}$ \\
\hline 2. & $\begin{array}{l}\text { Siswa memperhatikan } \\
\text { penjelasan guru }\end{array}$ & $\begin{array}{l}\text { Siswa sangat antusias dalam mendengarkan } \\
\text { penjelasan dari guru dan siswa sangat aktif } \\
\text { menjawab pertanyaan dari guru kemudian } \\
\text { menanyakan apa yang belum diketahuinya. Selama } \\
\text { guru menerangkan pelajaran siswa sangat tenang } \\
\text { dan tidak mengganggu teman yang lain. Siswa } \\
\text { sangat tanggap dengan apa yang diinstruksikan oleh } \\
\text { guru. }\end{array}$ \\
\hline 3. & $\begin{array}{l}\text { Siswa fokus mengamati } \\
\text { objek pengamatan }\end{array}$ & $\begin{array}{l}\text { Siswa sangat bersemangat dan antusias saat } \\
\text { diberikan tugas individu maupun tugas kelompok } \\
\text { oleh guru. Saat kerja kelompok siswa mengerjakan } \\
\text { tugas kelompok dengan baik. Siswa juga } \\
\text { menanyakan hal-hal yang belum diketahuinya } \\
\text { dengan cara mengacungkan tangan. Setelah diskusi } \\
\text { siswa juga diberikan kesempatan untuk } \\
\text { mempresentasikan hasil kerja kelompok ke depan } \\
\text { kelas. }\end{array}$ \\
\hline 4. & $\begin{array}{l}\text { Siswa mengajukan } \\
\text { pertanyaan dan berdiskusi }\end{array}$ & $\begin{array}{l}\text { Saat guru menerangkan didepan kelas siswa aktif } \\
\text { menanyakan apa yang belum dimengerti. Ketika ada } \\
\text { hal yang belum diketahui siswa aktif bertanya } \\
\text { kepada guru. Pada akhir pembelajaran siswa dan }\end{array}$ \\
\hline
\end{tabular}




\begin{tabular}{|c|c|c|}
\hline & & $\begin{array}{l}\text { guru bersama-sama menyimpulkan materi yang } \\
\text { telah dipelajari. }\end{array}$ \\
\hline 5. & $\begin{array}{l}\text { Siswa menikmati proses } \\
\text { pembelajaran }\end{array}$ & $\begin{array}{l}\text { Saat pembelajaran dikelas interaksi antar siswa } \\
\text { terjalin dengan baik. Jika ada siswa yang belum } \\
\text { mengerti siswa yang lain memberikan penjelasan } \\
\text { kepada siswa tersebut. Ketika ditunjuk oleh guru } \\
\text { untuk membuat pernyataan terimakasih siswa } \\
\text { langsung bisa menjawab dengan benar. Dan juga } \\
\text { ketika berbicara dengan temannya siswa } \\
\text { menggunakan Bahasa yang baik dan sopan. Pada } \\
\text { saat temannya presentasi didepan kelas siswa yang } \\
\text { lain aktif memberikan tanggapannya dan } \\
\text { memberikan tepuk tangan pada setiap penampilan } \\
\text { siswa. }\end{array}$ \\
\hline 6. & $\begin{array}{l}\text { Siswa memanfaatkan } \\
\text { fasilitas media dan alat } \\
\text { peraga yang ditampilkan }\end{array}$ & $\begin{array}{l}\text { Pada saat pembelajaran guru menggunakan fasilitas } \\
\text { papan tulis untuk mendukung pembelajaran. Selain } \\
\text { itu siswa juga disuruh untuk membuat kartu ucapan } \\
\text { terima kasih dan berbalasan dengan temannya. } \\
\text { Ketika ditunjuk untuk maju kedepan siswa dengan } \\
\text { percaya diri membacakan ucapan terimakasih pada } \\
\text { media surat. }\end{array}$ \\
\hline
\end{tabular}

\section{PEMBAHASAN}

Keterampilan guru dalam mengadakan variasi pembelajaran tematik kelas $1 \mathrm{~A}$ dan IB di SDN 1 Gondang telah dilakukan guru secara baik dan bervariatif. Guru sudah sepenuhnya memahami bahwa mengadakan variasi pembelajaran merupakan kegiatan guru dalam menghilangkan kejenuhan atau kebosanan siswa saat mengikuti pembelajaran sehingga proses belajar mengajar dapat berjalan dengan baik sesuai dengan yang diharapkan. Saat mengajar dari kegiatan awal hingga akhir, guru telah menunjukkan pemanfaatan keterampilan mengadakan variasi, seperti aspek penggunaan suara yang dikombinasi dengan variasi gaya mengajar lainnya.

Guru memberikan variasi suara dengan intonasi, kecepatan, dan nada yang sesuai dengan situasi dan kondisi kelas pada saat itu. Pada saat menjelaskan materi guru menggunakan suara yang lembut dan memberikan penekanan pada saat menjelaskan poin-poin penting. Ekspresi ceria dan bersemangat dengan diimbangi gerakan tangan dilakukan guru untuk memperjelas penyajiannya. Ketika terdapat 
siswa yang gaduh, guru menggunakan suara keras dengan nada tinggi untuk menarik perhatian siswa. Setelah kelas kembali tenang, guru mengatur suaranya normal kembali dengan suara lembut. Penekanan dilakukan guru saat menyampaikan materi kepada siswa yaitu dengan cara mengulang dan memperjelas poin-poin materi yang di anggap penting. Penekanan tersebut dilakukan dengan dikombinasi gerakan anggota badan dengan perubahan mimik wajah, sehingga bisa menarik perhatian siswa. Ketika menjelaskan materi guru menggunakan kata-kata yang jelas, mudah dimengerti dan lancar dalam penyampaiannya.

Kesenyapan dilakukan guru sengaja dengan maksud memberikan kesempatan kepada siswa untuk berpikir pada saat diberikan pertanyaan oleh guru atau pemberian waktu untuk mencatat hal-hal penting setelah guru menjelaskan. Hal ini dilakukan agar siswa benar-benar konsentrasi memperhatikan penjelasan guru. Selain itu, guru juga sering menggunakan waktu/kesenyapan untuk menghentikan keributan siswa. Ketika terdapat siswa yang ribut, guru tiba-tiba diam sejenak seperti mematung untuk menarik perhatian siswa kembali.

Kontak pandang yang dilakukan guru dengan siswa dilakukan secara merata tidak hanya pada satu titik saja. Guru juga tanpa ragu memandang siswa yang melakukan hal yang dirasa mengganggu proses pembelajaran. Hal tersebut dilakukan guru sambil berdiri di depan kelas, ketika duduk dikursi guru maupun ketika berada di dekat siswa yang melakukan kegaduhan sebagai tanda teguran untuk siswa tersebut. Pada saat siswa mengajukan pertanyaan guru menatap siswa dan melakukan kontak pandang menyeluruh. Pemberian kontak pandang tersebut dimaksudkan agar guru bisa menjangkau seluruh siswa dan mengerti siswa mana yang memperhatikan mana yang tidak memperhatikan pada saat pembelajaran berlangsung.

Ketika mengajar, perubahan posisi guru bervariasi dan tidak monoton seperti duduk atau berdiri ditempat yang sama dalam waktu yang lama. Guru biasanya berdiri di depan kelas kemudian ke tengah, samping kiri dan kanan juga ke belakang selama masih dapat dilihat seluruh siswa ketika menjelaskan, terkadang menghampiri siswa ketika mengerjakan tugas dan ketika ada siswa yang bertanya. Perubahan posisi yang dilakukan guru masih bersifat wajar atau tidak berlebihan sehingga tidak mengganggu konsentrasi siswa. 
Pada proses pembelajaran gerakan anggota badan yang dilakukan guru juga selalu diperhatikan oleh siswa. Variasi gerakan anggota badan dilakukan guru dengan menggerakkan tangan saat berbicara, guru menggelengkan kepala saat siswa salah atau kurang tepat menjawab pertanyaan, dan menggunakan mimik wajah yang sesuai dengan penjelasan yang diberikan. Penggunaan variasi ini selain untuk menarik perhatian siswa juga bertujuan untuk memperjelas arti pembicaraan yang disampaikan guru.

Ketika menyampaikan materi guru memanfaatkan media yang ada di lingkungan sekitar sekolah, misalnya pohon, batu dan benda-benda konkrit lainnya. Penggunaan variasi media lumayan baik untuk kedua kelas yang diteliti terlihat dari penggunaan benda-benda yang ada di sekitar sekolah dan menggunakan siswa sebagai model. Namun penggunaan media belum dilaksanakan dengan maksimal oleh guru dikarenakan masih terbatasnya alat peraga yang tersedia di kelas dan juga karena usia guru yang hampir purna sehingga guru tidak begitu kreatif untuk selalu membuatkan media pada setiap pembelajaran. Guru juga menggunakan media taktil yaitu memberikan kesempatan kepada siswa untuk memanfaatkan fasilitas yang ada di kelas seperti kapur dan papan tulis. Penggunaan variasi media tersebut mampu membangkitkan minat belajar siswa.

Penampilan guru dalam pemanfaatan pola interaksi baik itu pola interaksi satu arah, dua arah, ataupun multi arah dalam kegiatan siswa terlihat serius tetapi santai dan terjadi hubungan yang baik dan menyenangkan. Serius dalam arti tetap semangat belajar dan sungguh-sungguh, namun tetap santai tanpa rasa tegang, tertekan, takut terhadap guru atau hal-hal lain yang menyebabkan proses belajar mengajar kurang menyenangkan. Sikap guru yang humoris dan bersahabat dengan siswa timbul karena guru tidak pernah berkata kasar, marah yang berlebihan, ataupun bertindak sesuatu yang menyinggung perasaan. Sehingga pembelajaran menjadi menyenangkan dam siswa dapat mengikuti pelajaran dengan sungguh-sungguh tanpa rasa takut dan tegang.

Selama pengamatan, secara umum guru kelas 1 di SDN 1 Gondang sudah menunjukkan adanya pemanfaatan keterampilan mengadakan variasi mengajar dengan terampil dan apa adanya. Guru telah mamanfaatkan ketiga komponen variasi mengajar yang telah disampaikan oleh Djamarah (2010, hal. 167-172), yaitu variasi 
gaya mengajar, variasi penggunaan media dan bahan ajar, dan variasi pola interaksi untuk menghilangkan kejenuhan siswa. Selain itu, variasi mengajar ini sudah digunakan oleh kedua guru secara berkesinambungan, apa adanya, dan sudah mampu mendorong peserta didik untuk belajar.

Respon siswa yang ditunjukkan oleh para siswa di kelas IA dan IB terdapat timbal balik dari aktivitas mengajar yang dilaksanakan oleh guru. Pada awal pembelajaran siswa sudah menunjukkan kesiapannya. Dengan variasi pembelajaran yang diberikan oleh guru siswa tampak aktif, konsentrasi dan antusias mengikuti serangkaian kegiatan pembelajaran. Siswa terlihat semangat dalam mengikuti pelajaran dan mudah mengerti apa yang disampaikan oleh guru. Siswa juga mulai mengajukan dan mendiskusikan berbagai topik pembelajaran, baik dalam kelas maupun kelompok.

Jadi, dapat diambil simpulan bahwa guru kelas 1 di SDN 1 Gondang sudah mampu menerapkan keterampilan variasi mengajar dengan baik sesuai dengan teori yang ada dan selama kegiatan pembelajaran berlangsung dan guru sudah mampu menggunakan semua variasi mengajar dan penggunaannya juga sudah berkesinambungan berdampak baik pada respon siswa.

\section{SIMPULAN}

Berdasarkan hasil penelitian dan pembahasan yang telah diuraikan sebelumnya tentang keterampilan guru dalam mengadakan variasi pembelajaran tematik kelas 1 SDN 1 Gondang Kabupaten Tulungagung, dapat ditarik kesimpulan bahwa guru kelas awal telah mampu menguasai keterampilan dasar mengajar yakni dalam mengadakan variasi pembelajaran tematik dengan baik. Pengadaan variasi pembelajaran dilakukan melalui banyak cara, baik melalui gerak tubuh, suara, pola interaksi, pembentukan kelompok belajar, dan penggunaan media belajar.

Respon siswa terhadap variasi pembelajaran tematik yang dilakukan guru kelas 1 menunjukkan siswa selama mengikuti kegitan pembelajaran tematik sudah baik dan memperhatikan penjelasan dari guru. Pada awal pembelajaran siswa sudah menunjukkan kesiapannya yaitu dengan duduk rapi dan tenang dikursinya masingmasing dan menyiapkan buku tematik yang akan dipelajari. Dengan variasi pembelajaran yang diberikan oleh guru siswa tampak aktif, antusias dan konsentrasi selama mengikuti serangkaian kegiatan pembelajaran. Siswa juga mengajukan 
pertanyaan kepada guru mengenai hal yang belum dipahami dan mendiskusikan tugas dengan kelompoknya.

\section{DAFTAR PUSTAKA}

Arikunto, S. (2013). Prosedur Penelitian Suatu Pendekatan Praktik. Jakarta: PT. Rineka Cipta.

Djamarah, \& Zain, Aswan. (2010). Strategi Belajar Mengajar. Jakarta: Rineka Cipta.

Djamarah. (2010). Guru \& Anak Didik dalam Interaksi Edukatif. Jakarta: PT Rineka Cipta

Fadlilah. (2014). Implementasi Kurikulum 2013 Dalam Pembelajaran SD/MI, $S M P / M T S, \& S M A / M A$. Yogyakarta: Ar-Ruzz Media.

Hamalik, Oemar. (2008). Proses Belajar Mengajar. Jakarta: Bumi Aksara

Majid, Abdul. (2014). Pembelajaran Tematik Terpadu. Bandung: PT Remaja Rosdakarya

Moleong. (2012). MetodePenelitian Kualitatif. Bandung: PT Remaja Rosdakarya.

Mulyasa E. (2013). Menjadi Guru Profesional Menciptakan Pembelajaran Kreatif Menyenankan.Bandung: PT. Remaja Rosdakarya.

Sadirman. (2011). Interaksi \& Motivasi Belajar Mengajar. Jakarta: Rajawali Press.

Sugiyono. (2018). Metode Penelitian Pendidikan Kuantitatif Kualitatif dan R\&D. Bandung: Alfabeta.

Trianto. (2007). Model Pembelajaran Terpadu Dalam Teori Dan Praktek. Jakarta: Prestasi Pustaka.

Usman, Uzer. (2013). Menjadi Guru Profesional. Bandung: PT Remaja Rosdakarya. 